\title{
Immune reconstitution and graft-versus-host reactions in rat models of allogeneic hematopoietic cell transplantation
}

\author{
Severin Zinöcker ${ }^{1,2}{ }^{*}$, Ralf Dressel ${ }^{3}$, Xiao-Nong Wang $^{4}$, Anne M. Dickinson $^{4}$ and Bent Rolstad ${ }^{1}$ \\ 1 Department of Anatomy, Institute of Basic Medical Sciences, University of Oslo, Oslo, Norway \\ ${ }^{2}$ Department of Immunology, Oslo University Hospital - Rikshospitalet, Oslo, Norway \\ ${ }^{3}$ Department of Cellular and Molecular Immunology, University Medical Center Göttingen, Göttingen, Germany \\ ${ }^{4}$ Department of Haematological Sciences, Institute of Cellular Medicine, Medical School, Newcastle University, Newcastle-upon-Tyne, UK
}

\section{Edited by:}

Antoine Toubert, Université Paris Diderot and Assistance

Publique-Hôpitaux de Paris, France

Reviewed by:

Philippe Saas, Etablissement Français du Sang, France

Pascale Loiseau, Assistance

Publique-Hôpitaux de Paris, France

*Correspondence:

Severin Zinöcker, Laboratory of Immunogenetics, National Institute of Allergy and Infectious Diseases, National Institutes of Health, 12441 Parklawn Drive, MSC 8180, Rockville, MD 20852, USA.

e-mail: zinockers@mail.nih.gov
Allogeneic hematopoietic cell transplantation (alloHCT) extends the lives of thousands of patients who would otherwise succumb to hematopoietic malignancies such as leukemias and lymphomas, aplastic anemia, and disorders of the immune system. In alloHCT, different immune cell types mediate beneficial graft-versus-tumor (GvT) effects, regulate detrimental graft-versus-host disease (GvHD), and are required for protection against infections. Today, the "good" (GvT effector cells and memory cells conferring protection) cannot be easily separated from the "bad" (GvHD-causing cells), and alloHCT remains a hazardous medical modality. The transplantation of hematopoietic stem cells into an immunosuppressed patient creates a delicate environment for the reconstitution of donor blood and immune cells in co-existence with host cells. Immunological reconstitution determines to a large extent the immune status of the allo-transplanted host against infections and the recurrence of cancer, and is critical for long-term protection and survival after clinical alloHCT. Animal models continue to be extremely valuable experimental tools that widen our understanding of, for example, the dynamics of post-transplant hematopoiesis and the complexity of immune reconstitution with multiple ways of interaction between host and donor cells. In this review, we discuss the rat as an experimental model of HCT between allogeneic individuals. We summarize our findings on lymphocyte reconstitution in transplanted rats and illustrate the disease pathology of this particular model. We also introduce the rat skin explant assay, a feasible alternative to in vivo transplantation studies. The skin explant assay can be used to elucidate the biology of graft-versus-host reactions, which are known to have a major impact on immune reconstitution, and to perform genome-wide gene expression studies using controlled combinations of minor and major histocompatibility between the donor and the recipient.

Keywords: hematopoietic stem cell transplantation, graft-versus-host disease, rodentia, animal models, skin explant assay

\section{HEMATOPOIETIC CELL TRANSPLANTATION IN HUMANS AND ANIMALS}

At present, approximately 25,000 allogeneic hematopoietic cell transplantations (alloHCT) are performed each year worldwide, and the total number of such clinical procedures is predicted to rise in the future (Savani et al., 2011). AlloHCT can give rise to considerable toxicity and negative side-effects resulting in relatively high morbidity and mortality with poor quality of life and 5 -year survival rates of $40-60 \%$ overall. It is however the only curative therapy in patients with relatively severe and advanced diseases for whom other treatment options are limited.

To date, alloHCT is complicated by opportunistic infections, disease relapse and graft-versus-host disease (GvHD). GvHD is an immunological condition that is caused by the reactivity of allogeneic $\mathrm{T}$ cells transferred in the stem cell graft from a genetically related or unrelated donor. After activation through recognition of disparate host antigens, alloreactive cells exert pathological damage via cytotoxic mechanisms and cytokine release on various organs and tissues, primarily the liver, gut, and skin, of the immunocompromised transplant recipient (Ferrara et al., 2008). In the clinical setting, relatives are favored over unrelated volunteer stem cell donors because of genetic similarity with the patient, reducing the overall risk of transplant failure and adverse graft-versus-host reactions (GvHR).

Immunity is deficient after alloHCT due to underlying disease, pre-transplant conditioning, or both, and it takes weeks to several months or years for the patient's immune system to recover (Storek, 2008; Seggewiss and Einsele, 2010; Bosch et al., 2012). Early after transplantation, the reconstitution of immune cells in lymphoid organs is inhibited: the primary sites of white and red blood cell generation, bone marrow and thymus, are damaged by chemotherapy and radiation conditioning, and they are targeted by GvHD (Krenger and Holländer, 2008; Shono et al., 2010). Furthermore, immune function is impaired in elderly patients (Krenger et al., 2011) as both the regeneration of hematopoietic cells in the bone marrow and the thymic 
output of T lymphocytes decrease with age (Dorshkind et al., 2009).

Deficient and delayed restoration of immunity post-transplant contributes to the patient's susceptibility to opportunistic infections, recurrence of the original disease and occurrence of secondary malignancies (Toubert et al., 2012). The individual contributions of natural killer (NK) cells, $\mathrm{CD} 8^{+}$cytotoxic $\mathrm{T}$ cells, $\mathrm{CD} 4^{+}$ helper T cells, B cells, and innate immune cells, and their combined effects on these complications are still not fully understood (Geddes and Storek, 2007; Bosch et al., 2012).

Moreover, T cell depletion of the graft, when applied to reduce the risk of GvHD and essential in haploidentical alloHCT between family members (Kolb, 2008), compromises immune reconstitution, illustrating that grafted "passenger" $\mathrm{T}$ cells are needed for successful engraftment. Depletion of $\mathrm{T}$ cells also abrogates the graft-versus-tumor (GvT) effect, as $\mathrm{GvH}$ and GvT effects are strongly correlated and transplanted donor $\mathrm{T}$ cells can either mediate beneficial GvT effects or cause GvHD (Appelbaum, 2001). The crucial question of how to avoid detrimental GvHR without compromising the curative potential of alloHCT through a strong GvT effect has yet to be solved by clinical hematologists and HCT researchers.

\section{THE USEFULNESS OF ANIMAL MODELS IN STUDYING HEMATOPOIETIC CELL TRANSPLANTATION AND GRAFT-VERSUS-HOST DISEASE}

The wish to better understand the dynamic biological processes between graft and host following transplantation, with the overall aim to improve the clinical management of alloHCT, has driven research in the development of adequate laboratory methods and animal models. The use of such models in transplantation research has contributed substantially to our current understanding of the nature of GvHR and its underlying principles in GvHD (Welniak et al., 2007; Socié and Blazar, 2009). Experimental alloHCT using mice and dogs have been particularly instrumental for the discovery of a variety of new therapies and for testing their feasibility, toxicity, and efficacy (Ferrara et al., 2008; Socié and Blazar, 2009).

Inbred rodent strains can be systematically established and maintained, yielding genetically homogeneous and biologically well-characterized strains for experimentation. Experiments in live animals facilitate and accelerate, for example, the study of genetic effects and mapping of gene associations with observable pathological phenotypes. An array of murine experimental models that employ donor and host strain combinations designed for mismatches only in the major histocompatibility complex (MHC) gene region ( $\mathrm{H}-2$ in the mouse), only in minor histocompatibility antigens, or both, are available for the study of immune reconstitution and GvHD (Schroeder and DiPersio, 2011). Fully incompatible strain combinations, such as the popular [C57BL/6 $\left(H-2^{b}\right) \rightarrow$ Balb/C $\left(H-2^{d}\right)$ ] mouse model, are most often applied. Combinations of mice strains that are MHC matched but differ in minor histocompatibility antigens, for example $\left[\mathrm{B} 10 . \mathrm{D} 2\left(H-2^{d}\right) \rightarrow \mathrm{Balb} / \mathrm{C}\left(H-2^{d}\right)\right],\left[\mathrm{DBA} / 2\left(H-2^{d}\right) \rightarrow \mathrm{B} 10 . \mathrm{D} 2\right.$ $\left.\left(H-2^{d}\right)\right]$, or $\left[\mathrm{C} 3 \mathrm{H} . \mathrm{SW}\left(H-2^{b}\right) \rightarrow \mathrm{C} 57 \mathrm{BL} / 6\left(H-2^{b}\right)\right]$ transplantation models (Korngold and Sprent, 1987), can mimic fully human leukocyte antigen (HLA) matched HCT between unrelated individuals, but not semi-HLA compatible HCT between sibling pairs. The latter scenario of haploidentical HCT between first-degree relatives can be modeled by inter-crossing two inbred strains and using the resulting hybrid progeny of the $\mathrm{F}_{1}$ generation as recipients of a transfusion of parental leukocytes in so-called parent-into- $\mathrm{F}_{1}$ models.

The mouse is historically and presently the most widely used model in biomedical research. However, other animal models have the potential to complement, validate, and extend the findings from experiments on mice. Studies of alloHCT in dogs make a case in point as they have added important knowledge in this field of research (Storb and Thomas, 1985), e.g., the use of delayed donor lymphocyte infusions to induce a GvT reaction and non-myeloablative ("reduced intensity") conditioning regimens to reduce toxicity and morbidity in patients. Murine models have been employed to test non-myeloablative conditioning regimens with reduced irradiation intensity and/or combination chemotherapy (fludarabine, busulfan, cyclophosphamide, etc.; Santos and Owens, 1969; Ruggeri et al., 2002; Sadeghi et al., 2008). Similarly, rat alloHCT models based on chemotherapeutic conditioning without the need for irradiation have been developed (Santos and Owens, 1966; Tutschka and Santos, 1975; Okayama et al., 2004).

Rats offer all the advantages of a rodent experimental model, such as short generation time and cost effectiveness. Rats are bigger than mice (about 10-fold in body weight) and thus yield more grams of biological material per animal and per cage unit that can be sampled in the course of experimentation. Their spleens, lymph nodes, efferent lymph, and peripheral blood contain lymphocytes that can be readily harvested and serve as organ sources of donor grafts for transplantation. Hematopoietic stem cells are commonly obtained from the marrow of large bones (e.g., femurs and tibiae). Cell grafts enriched in Sca- $1^{+}$and $\mathrm{CD} 34^{+}$hematopoietic stem cells that are being used in patients and experimentally in mice have not been available for rat models due to the lack of specific antibody markers for targeted cell purification.

Many genetically defined and well-characterized inbred rat strains are available for research in transplantation immunology, and a range of rat alloHCT models have been developed from these strains during the past decades. Especially the strains BrownNorway (BN) and Lewis (LEW) are widely used for fully MHC mismatched alloHCT (Santos and Owens, 1966; Clancy et al., 1976; Pakkala et al., 2001; Okayama et al., 2004; Zhu et al., 2011; Lin et al., 2012). Also HCT between haploidentical parental and filial generations, e.g., transplantation of LEW or $\mathrm{BN}$ bone marrow into $\mathrm{F}_{1}$ $(\mathrm{BN} \times \mathrm{LEW})$ recipients, has been modeled in the rat (Clancy et al., 1983; Kimura et al., 1995; Ohajekwe et al., 1995; Peszkowski et al., 1996; Vaidya et al., 1996; Goral et al., 1998; Kobayashi et al., 1998; Sasatomi et al., 2005; Wolff et al., 2006; Kitazawa et al., 2012). In a number of these models, engraftment, reconstitution, chimerism, cell trafficking, and tolerance toward donor cells has been studied (Clancy et al., 1983; Oaks and Cramer, 1985; Ohajekwe et al., 1995; Engh et al., 2001; Foster et al., 2001; Okayama et al., 2004; Itakura et al., 2007; Klimczak et al., 2007; Nestvold et al., 2008; Zhou et al., 2008; Zhu et al., 2011; Zinöcker et al., 2011a;Lin et al., 2012). Furthermore, rat models have been employed to test prevention or treatment of GvHD by therapeutic regimens involving immunomodulatory drugs (Tutschka et al., 1979; Vogelsang et al., 1986; Vogelsang et al., 1988; Mrowka et al., 1994; Ohajekwe et al., 
1995; Pakkala et al., 2001; Okayama et al., 2006; Wolff et al., 2006; Jäger et al., 2007), infusion or induction of various suppressive cell types (Itakura et al., 2007; Aksu et al., 2008; Nestvold et al., 2008; Kitazawa et al., 2010; Zinöcker et al., 2011b; Kitazawa et al., 2012; Zinöcker et al., 2012), UV irradiation (Ohajekwe et al., 1995; Gowing et al., 1998), serum transfusion (Shimizu et al., 1997), surgical techniques (Kobayashi et al., 1998), and prolonged distribution of a chemical agent with subcutaneously implanted osmotic pumps (Fidler et al., 1993).

The $\mathrm{MHC}$ is the dominant genomic region that governs mutual tolerance, rejection, and GvHR between the donor and the host in alloHCT. The mouse and rat MHC regions are closely related and share overall similarity with the human MHC (HLA; Kelley et al., 2005a), however, some important structural differences exist. In particular, the rat MHC (RT1) differs from the mouse MHC region in that it encompasses a large number of polymorphic nonclassical MHC class I genes which serve as potential ligands for NK cell receptors (Vance et al., 1998; Naper et al., 2002; Naper et al., 2005; Kveberg et al., 2010; Andrews et al., 2012). In addition, the rat genome encodes a broader spectrum of inhibitory and activating Ly49 receptors expressed by NK cells compared to the mouse (Kelley et al., 2005b). Therefore, alloreactive rat NK cells and NK cell subsets may behave differently than mouse NK cells in the context of transplantation. Transplanted donor-versus-recipient NK cells mediate both GvT and GvH effects in patients (Ruggeri et al., 2002). They are thus a key element in the risk of leukemia relapse after haploidentical alloHCT (Velardi, 2012) and could influence T cell alloreactivity and the development of GvHR. The considerable differences especially in the NK cell system even between closely related species like rat and mouse illustrate the importance of relying on more than one experimental animal model in HCT research.

The complete genome sequence of Rattus norvegicus has been resolved in 2004 (Rat Genome Sequencing Project Consortium, 2004). With the advent of commercial cloning technology for rats (Huang et al., 2011) this species will likely be applied more frequently as a study object in the future. In the following sections, we will discuss some contributions by which rat models have helped to advance our understanding of immune reconstitution and GvHR following alloHCT.

\section{THE RAT AS AN IN VIVO MODEL OF IMMUNE RECONSTITUTION AND GRAFT-VERSUS-HOST REACTIONS AFTER HEMATOPOIETIC CELL TRANSPLANTATION}

To study the role of GvHR on immune reconstitution in vivo, we employed experimental transplantation protocols using combinations of rat strains with defined genetic incompatibilities (Engh et al., 2001; Nestvold et al., 2008; Zinöcker et al., 2012). The genetic composition regarding the $\mathrm{MHC}$ region of relevant rat strains are listed in Table 1. For experiments on fully incompatible (mismatched at the $\mathrm{MHC}$ region as well as non-MHC genes) alloHCT, we employed a model using Piebald Virol Glaxo (PVG) rats as the donor strain and $\mathrm{BN}$ rats as recipients of transplants. Conveniently, the genetic make-up of the donor PVG.7B strain encodes an allele (the RT7.2 allotype) of the CD45 gene (Kampinga et al., 1990), which facilitates later detection of donor-derived cells distinguishable from host-derived cells by flow cytometry using
Table 1 | MHC haplotypes of inbred congenic and recombinant rat strains.

\begin{tabular}{llll}
\hline Rat strain & \multicolumn{3}{c}{ MHC subregion } \\
\cline { 2 - 4 } & Classical class I & Class II & Non-classical class I \\
& $R T 1-A$ & $R T 1-B / D$ & $R T 1-C E / N / M$ \\
\hline
\end{tabular}

\begin{tabular}{llll}
\hline BN & $n$ & $n$ & $n$ \\
LEW & $l$ & $l$ & $l$ \\
LEW.1N & $n$ & $n$ & $n$ \\
PVG & $c$ & $c$ & $c$ \\
PVG.7B & $c$ & $c$ & $c$ \\
PVG.1N & $n$ & $n$ & $n$ \\
PVG.1U & $u$ & $u$ & $u$ \\
PVG.R23 & $u$ & $a$ & $a v 1$ \\
\hline
\end{tabular}

allotype-specific antibody. The genetic background of the PVG.7B strain is identical with the original PVG strain; both carry the $c$ haplotype of the rat $\mathrm{MHC}$, i.e., $R T 1^{c}$ (Table 1). The recipient BN strain has a different genetic background and carries the $n$ haplotype of $R T 1, R T 1^{n}$.

The reconstitution of blood and immune cells, especially of T lymphocytes, has been extensively studied in patients (Holland et al., 2008; Toubert et al., 2012), however, the mechanisms behind reconstitution and immunodeficiency and the complex interactions between donor and host cell types in this context remain incompletely understood. Many useful insights into the underlying cellular and molecular processes have been gained from experiments done mainly in mice. Immune reconstitution and post-transplant immune responses have been characterized also in the laboratory rat to some detail, facilitating the design of new transplantation protocols (Nestvold et al., 2008). The main rat blood cell types and cell subsets with relevance to HCT and their standard phenotypic characterization are summarized in Table 2.

One important aim of our studies was to describe in detail the reconstitution of the lymphocytes that mediate GvT and $\mathrm{GvH}$ effects, i.e., T cells and NK cells, in bone marrow recipients and in experimental GvHD. The experimental protocol used in these studies (Zinöcker et al., 2011a; adapted from Nestvold et al., 2008) is schematically outlined in Figure 1. Recipient rats received a lethal dose of $900 \mathrm{cGy}$ total body irradiation from a Cesium-137 source emitting $\beta$ and $\gamma$ irradiation at an approximate rate of $4 \mathrm{~Gy} \mathrm{~min}^{-1}$. This conditioning regimen made recipient rats susceptible to donor engraftment. Donor bone marrow containing hematopoietic stem cells was obtained from leg bones (femurs and tibiae). The graft consisted of mononuclear bone marrow cells that were depleted of T cells by negative selection using magnetic beads with anti- $\alpha \beta$ TCR and anti-CD5 antibodies (cf. Table 2) prior to transplant (Nestvold et al., 2008). Thus, the primary graft served to establish stable donor engraftment. In this model, the transfer of donor-versus-recipient reactive NK cells (Løvik et al., 1995) contained in the graft should facilitate engraftment and donor reconstitution. GvT effects can be studied after injecting BN acute myelocytic leukemia cells, a model of human acute myeloid leukemia (Martens et al., 1990), into BN recipients (Nestvold et al., 2008). Transplanted rats were convalescent for 14 days before 
Table 2 | Immunophenotype of rat leukocyte populations.

\begin{tabular}{|c|c|c|c|}
\hline Cell type & Phenotype & Antibody & Reference \\
\hline \multirow[t]{2}{*}{ Leukocyte } & $\mathrm{CD}_{4} 5^{+}$ & OX-1 & Sunderland et al. (1979) \\
\hline & ${\mathrm{MHC}-\mathrm{I}^{+}}^{+}$ & OX-18 & Fukumoto et al. (1982) \\
\hline \multirow[t]{4}{*}{ T lymphocyte } & $\mathrm{CD} 2^{+}$ & OX-34 & Jefferies et al. (1985) \\
\hline & $\mathrm{CD}^{+}$ & $\mathrm{G} 4.18$ & Nicolls et al. (1993) \\
\hline & $\mathrm{CD}^{+}$ & OX-19 & Dallman et al. (1984) \\
\hline & $\mathrm{CD}^{+}$ & OX-52 & Castro et al. (2003) \\
\hline$\alpha \beta T$ cell & TCR $\alpha \beta^{+}$ & R73 & Hünig et al. (1989) \\
\hline \multirow[t]{2}{*}{ CD4 $\alpha \beta$ T cell } & $\mathrm{CD}^{+}{ }^{+}$ & W3/25 & Williams et al. (1977) \\
\hline & & OX-38 & Jefferies et al. (1985) \\
\hline CD8 $\alpha \beta$ T cell & $\mathrm{CD} 8 \alpha^{+}$ & OX-8 & Brideau et al. (1980) \\
\hline \multirow[t]{2}{*}{ Naive T cell } & $\mathrm{CD}_{25}^{-}$ & OX-39 & Paterson et al. (1987) \\
\hline & CD45RC ${ }^{h i}$ & OX-22 & Spickett et al. (1983) \\
\hline T blast & $\mathrm{CD} 25^{+}$ & OX-39 & Paterson et al. (1987) \\
\hline CD4 T blast & $\mathrm{CD}_{134^{+}}$ & OX-40 & Paterson et al. (1987) \\
\hline \multirow{3}{*}{$\begin{array}{l}\text { Memory } \\
\text { T cell }\end{array}$} & CD62 $\mathrm{L}^{-}$ & OX-85 & Seddon et al. (1996) \\
\hline & & & \\
\hline & $\mathrm{CD}_{45 \mathrm{RC}} \mathrm{lo}^{\circ}$ & OX-22 & Spickett et al. (1983) \\
\hline \multirow{4}{*}{$\begin{array}{l}\text { Regulatory CD4 } \\
T \text { cell }\end{array}$} & $\mathrm{CD} 45 \mathrm{RC}^{10}$ & OX-22 & Powrie and Mason \\
\hline & & & (1990) \\
\hline & $\mathrm{CD}_{25} 5^{+}$ & OX-39 & $\begin{array}{l}\text { Stephens and Mason } \\
(2000)\end{array}$ \\
\hline & $\mathrm{FoxP}^{+}$ & FJK-16s & Beyersdorf et al. (2005) \\
\hline Regulatory & $\mathrm{CD} 45 \mathrm{RC}^{10}$ & OX-22 & Xystrakis et al. (2004b) \\
\hline CD8T cell & $\mathrm{FoxP}^{+}$ & FJK-16s & Han et al. (2007) \\
\hline$\gamma \delta \mathrm{T}$ cell & TCR $\gamma \delta^{+}$ & V65 & Kühnlein et al. (1994) \\
\hline \multirow[t]{3}{*}{ B lymphocyte } & $\mathrm{CD} 4 \mathrm{RA}^{+}$ & OX-33 & Woollett et al. (1985) \\
\hline & $\mathrm{MHC}-\mathrm{II}^{+}$ & OX-6 & McMaster and Williams \\
\hline & & & (1979) \\
\hline \multirow[t]{2}{*}{ Activated B cell } & $\mathrm{CD} 80^{+}$ & $3 \mathrm{H} 5$ & Maeda et al. (1997) \\
\hline & $\mathrm{CD} 6^{+}$ & $24 \mathrm{~F}$ & Maeda et al. (1997) \\
\hline \multirow[t]{3}{*}{ NK lymphocyte } & $\mathrm{CD}^{-}$ & G4.18 & Nicolls et al. (1993) \\
\hline & CD161a $a^{+}$ & 3.2 .3 & Na et al. (1992) \\
\hline & (NKR-P1A) & $10 / 78$ & Chambers et al. (1992) \\
\hline \multirow[t]{3}{*}{ NKT lymphocyte } & $\mathrm{CD}^{+}$ & G4.18 & Nicolls et al. (1993) \\
\hline & CD161a $a^{+}$ & 3.2 .3 & Na et al. (1992) \\
\hline & (NKR-P1A) & $10 / 78$ & Chambers et al. (1992) \\
\hline \multirow[t]{6}{*}{ Macrophage } & $\mathrm{MHC}-\mathrm{II}^{+}$ & OX-6 & McMaster and Williams \\
\hline & & & (1979) \\
\hline & $\mathrm{CD} 172 \mathrm{a}^{+}(\mathrm{SIRP} \alpha)$ & OX-41 & Robinson et al. (1986) \\
\hline & $\mathrm{CD}_{11 \mathrm{c}^{+}}$ & OX-42 & Robinson et al. (1986) \\
\hline & $\mathrm{CD} 8^{+}$ & ED1 & Dijkstra et al. (1985) \\
\hline & & $\mathrm{ED} 2^{\mathrm{a}}$ & Dijkstra et al. (1985) \\
\hline \multirow[t]{4}{*}{ Dendritic cell } & $\mathrm{MHC}-\mathrm{II}^{+}$ & OX-6 & $\begin{array}{l}\text { McMaster and Williams } \\
\text { (1979) }\end{array}$ \\
\hline & $\mathrm{CD} 172 \mathrm{a}^{+}(\mathrm{SIRP} \alpha)$ & OX-41 & Robinson et al. (1986) \\
\hline & $\mathrm{CD}_{11} \mathrm{c}^{+}$ & OX-42 & Robinson et al. (1986) \\
\hline & $\alpha_{\mathrm{E} 2}$ integrin & OX-62 & $\begin{array}{l}\text { Brenan and Puklavec } \\
\text { (1992) }\end{array}$ \\
\hline
\end{tabular}

Phenotypic markers of rat leukocyte populations and subpopulations are summarized together with available antibodies commonly used for their flow cytometric detection. Comprehensive lists of rat antigens and specific antibodies have been published by Puklavec and Barclay (2001) and van den Berg et al. (2001). A list of OX antibodies can be found online at http://users.path.ox.ac.uk/ ciu/mrcmabs.html

${ }^{a}$ No $C D$ designation is assigned for the cognate antigen.

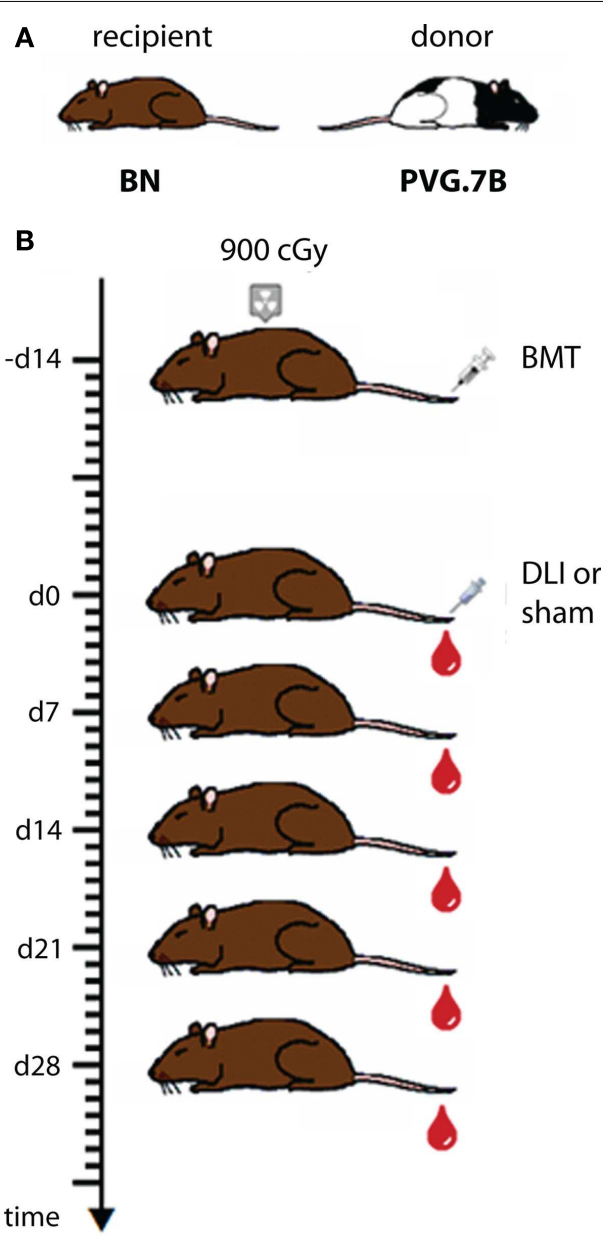

FIGURE 1 | Schematic outline of the transplantation protocol applied in the MHC mismatched rat model. (A) BN rats served as recipients and PVG.7B rats as bone marrow and lymph node donors for bone marrow transplantation (BMT) and donor lymphocyte infusion (DLI), respectively, in fully MHC-incompatible alloHCT performed as shown in (B). Recipient rats were lethally irradiated ( $900 \mathrm{cGy}$ ), rescued by an intravenous injection of donor bone marrow cells and 14 days later received a graded dose of donor lymph node cells to invoke fatal GvHD. Controls received sham treatment (injection without cells) instead of DLI. Blood samples were collected in weekly intervals from the day of DLI for subsequent analysis of reconstitution and chimerism.

GvHD was induced in a cell-dose dependent manner by a single infusion of donor lymphocytes (DLI; cf. Figure 1) from lymph nodes. Alternatively, GvHD can be invoked by transfusion of donor cells derived from the spleen or peripheral blood, and the latter source is highly relevant with regard to clinical GvHD, which is commonly caused by the transfer of $\mathrm{T}$ cells contained in a donor blood graft or donor lymphocyte transfusion.

\section{T cells, NK cells, and NKT cells}

With respect to lymphocyte reconstitution in recipients of clinical HCT, NK cells recover relatively swiftly (weeks) and T cell reconstitution happens more slowly (months to years; Storek et al., 2008). In our hands, both NKT and NK cells (as defined by CD3 and NKR-P1 surface expression; cf. Table 2) of donor origin were rapidly generated in animals transplanted with $\mathrm{T}$ 
cell-depleted bone marrow. NKT and NK cells of host origin were not detected in the circulation 2 weeks after HCT (Zinöcker et al., 2011a). Donor T cells showed a significantly slower pace of reconstitution in these animals, and reached approximately $90 \%$ donor chimerism in the blood only several months after transplant (Zinöcker et al., 2011a). Thus, the overall patterns of NK, NKT, and $\mathrm{T}$ lymphocyte reconstitution were similar to those observed in patients, albeit with accelerated kinetics as might be expected from a relatively short-lived rodent species.

Donor $\mathrm{CD} 4^{+} \mathrm{T}$ cells showed a tendency to reconstitute slightly more slowly than did donor $\mathrm{CD}^{+}{ }^{+} \mathrm{T}$ cells (Zinöcker et al., 2011a), which is also comparable with known clinical data (Seggewiss and Einsele, 2010). Rats that received an infusion of donor lymph node cells and subsequently developed GvHD displayed full donor chimerism of $\mathrm{CD}^{+}{ }^{+}$and $\mathrm{CD} 8^{+} \mathrm{T}$ cells shortly after DLI, coinciding with the onset of disease symptoms. This increase very likely reflected the activation by allo-antigens and rapid expansion of donor $\mathrm{CD}^{+}$and $\mathrm{CD}^{+} \mathrm{T}$ cell clones in the host. Any remaining host $\mathrm{T}$ cells were probably cleared by alloreactive donor cells.

\section{Memory T cells}

We also noted that donor-derived CD62L-expressing naive T cells were less frequent in the peripheral blood of rats that developed GvHD compared with healthy bone marrow-transplanted controls (Zinöcker et al., 2011a). This finding may likely be due to the loss of CD62L surface expression in the course of T cell activation as measured by the concomitant increase of CD25 and CD134 activation markers on $\mathrm{CD}^{+}{ }^{+}$and $\mathrm{CD}^{+} \mathrm{T}$ cell populations (cf. Table 2). Although we did not specifically investigate a memory $\mathrm{T}$ cell phenotype in our study, we speculate that donor memory $\mathrm{T}$ cells may expand in the presence of host allo-antigens and allo-activation as $\mathrm{CD}^{-} \mathrm{L}^{-} \mathrm{T}$ cells were more frequent in the circulation in rats with GvHD. CD44 ${ }^{+} \mathrm{CD}_{2} \mathrm{~L}^{-}$memory $\mathrm{T}$ cells that are generated in response to pathogens during infection as well as other antigens have been reported not to cause GvHD (Anderson et al., 2003; Chen et al., 2004). In line with these studies, Xystrakis et al. (2004a) have employed a parent-into-F 1 HCT model and showed that $\mathrm{CD} 4{ }^{+} \mathrm{CD} 45 \mathrm{RC}^{\text {lo }} \mathrm{T}$ cells containing mainly memory $\mathrm{T}$ cells, in contrast to $\mathrm{CD} 4{ }^{+} \mathrm{CD} 45 \mathrm{RC}{ }^{\text {hi }} \mathrm{T}$ cells containing mainly naive $\mathrm{T}$ cells, failed to induce acute or chronic GvHD in recipient rats. Conversely, transplanted memory $\mathrm{T}$ cells not specifically primed to allo-antigens can have a considerable potency to induce GvHD (Zheng et al., 2009). Therefore, the capacity of differentiated memory $\mathrm{T}$ cells to elicit a GvHR may depend on the nature of their primary antigen encounter.

\section{Regulatory T cells}

Furthermore, we found that host-derived FoxP3-expressing CD4 ${ }^{+}$ $\mathrm{CD}^{+} 5^{+} \mathrm{T}$ cells, comprising a regulatory $\mathrm{T}$ cell subtype (Beyersdorf et al., 2005), reconstituted relatively quickly and were present at normal levels in peripheral blood at 4 weeks post-transplant (Zinöcker et al., 2011a). It has been shown previously in mice that recipient $\mathrm{CD}^{+}{ }^{+} \mathrm{CD} 25^{+} \mathrm{T}$ cells can resist irradiation and regulate chronic GvHD (Anderson et al., 2004). Donor-type FoxP3 ${ }^{+}$ regulatory $\mathrm{T}$ cells, on the other hand, did not amount to significant numbers in the blood of transplanted rats at any time point post-transplant. Strikingly, and in contrast to transplanted controls which did not receive DLI, rats that suffered from GvHD failed to reconstitute FoxP3 ${ }^{+}$regulatory $\mathrm{T}$ cells completely. We speculate that the absence of regulatory $\mathrm{T}$ cells is a major contributing factor in the lack of ability of these animals to avert alloreactivity as they uniformly developed lethal GvHD. Another regulatory $\mathrm{T}$ cell subtype that was defined as $\mathrm{CD}^{+} \mathrm{CD}^{+} 5 \mathrm{RC}^{l o} \mathrm{FoxP} 3^{+}$in the rat (cf. Table 2$)$ suppressed alloreactive donor $\mathrm{CD} 4^{+} \mathrm{T}$ cells in vitro and prevented experimental GvHD in vivo (Xystrakis et al., 2004b). Decreased FoxP3 expression (Miura et al., 2004) and frequency of regulatory T cells (Zorn et al., 2005; Rieger et al., 2006; Magenau et al., 2010) has been associated with the incidence of GvHD in patients. Furthermore, $\mathrm{CD} 4{ }^{+} \mathrm{CD} 25^{+}$regulatory $\mathrm{T}$ cells have been shown to suppress host-reactive T cells and reduce acute GvHD in murine models (Cohen et al., 2002; Hoffmann et al., 2002; Taylor et al., 2002; Edinger et al., 2003). Alleviation of GvHD after infusion of donor-derived $\mathrm{CD} 4{ }^{+} \mathrm{CD} 25^{+}$regulatory $\mathrm{T}$ cells has recently been reported in some patients (Brunstein et al., 2011; Di Ianni et al., 2011), although these phase I clinical trials were not powered to assess the efficacy of this treatment modality and did not include control subjects. The therapeutic potential of regulatory $\mathrm{T}$ cell induction or adoptive transfer in GvHD prevention is currently under clinical exploration (Leventhal et al., 2012).

\section{B cells and antibodies}

In transplanted rats, B cells recover gradually in host lymphoid organs and peripheral blood with kinetics similar to that of $\mathrm{T}$ cells (Renkonen, 1986). This is consistent with what is known of $B$ cell reconstitution in patients who receive an allogeneic donor transplant (Bosch et al., 2012), as is the finding that B cell reconstitution is delayed during acute GvHD (Renkonen, 1986; Bosch et al., 2012). B cells did not recover in the skin, lungs, or the gut of host rats that developed acute GvHD, but accumulation of immunoglobulin-producing cells was observed in the inflamed liver (Renkonen et al., 1986). B cells are thought to participate in the pathogenesis of GvHD (Shimabukuro-Vornhagen et al., 2009), possibly by presenting allo-antigens and by secreting auto- and alloreactive antibodies.

Disparate MHC molecules and minor histocompatibility (nonMHC) antigens of both donor and host type co-exist in radiation chimeras, by which B cells can be activated to produce alloantibodies either against donor antigens (on hematopoietic cells) or against host antigens (mainly non-hematopoietic tissue). Putative donor-derived allo-antibodies will therefore bind mainly to tissue components of the host and may be difficult to detect in the serum unless circulating donor cells are screened for B cell receptor specificities. We know that the transfusion of PVG T cells into semi-allogeneic $\mathrm{F}_{1}(\mathrm{PVG} \times \mathrm{DA})$ hybrid recipients induces autoantibodies against basal membranes of the skin (Rolstad, 1985). Increased serum levels of antibodies against heat-shock proteins are associated with acute and chronic GvHD (Goral et al., 1995, 2002).

B cells play an important role in the etiology of chronic GvHD as increased auto-antibody titers and other autoimmune-typical symptoms are hallmarks of this disease (Ferrara et al., 2008). Laboratory rodents have been used to model chronic GvHD experimentally (Vogelsang et al., 1988; Schroeder and DiPersio, 2011). 
Spleen cell transfer without bone marrow transplantation from either BN or LEW donor strains induced autoreactive antibodies that are typical of an autoimmune-like chronic GvHR in $F_{1}$ $(\mathrm{LEW} \times \mathrm{BN})$ hybrid rats (Tournade et al., 1990; Xystrakis et al., 2004a). Interestingly, transfusions of LEW splenocytes resulted in acute GvHD and death of $F_{1}$ recipients, while transfusions of BN splenocytes caused no disease (Tournade et al., 1990; Xystrakis et al., 2004a). This may be due to different genetic factors in the respective donor strains and $\mathrm{T}$ cell responses that differ in the pattern of cytokine release upon allostimulation (Bernard et al., 2010). Studies done in our labs support the hypothesis that the quality of the allogeneic $\mathrm{T}$ cell response is important and depended on the tissue source: peripheral T cells typically induced acute GvHD (Nestvold et al., 2008) while bone marrow-derived $\mathrm{T}$ cells induced a more chronic form of the disease (Naper et al., 2010).

\section{ALLO-TRANSPLANTATION IN A SEMI-COMPATIBLE RAT MODEL}

Hematopoietic cell transplantations using fully MHC mismatched donors are not performed in the clinic because of the excessively high risk of GvHD. Previous efforts in our lab to generate a semicompatible (haploidentical) HCT model by cross-breeding inbred PVG and BN rats failed because of what appeared to be a significant heterosis effect that rendered the $\mathrm{F}_{1}(\mathrm{PVG} \times \mathrm{BN})$ offspring highly aggressive and impossible to handle. In another effort to design a model that reflects the clinical reality better than the completely mismatched [PVG.7B $\rightarrow \mathrm{BN}$ ] transplantation model, we selected rat strains that were partly matched at the $\mathrm{MHC}$ region. The PVG$R T 1^{r 23}$ strain (PVG.R23) and the PVG-RT1 ${ }^{u}$ strain (PVG.1U) are partially compatible: PVG.1U rats express the $u$ - $u$ - $u$ haplotype of $R T 1$ and PVG.R23 rats the intra-MHC recombinant $u$ - $a$-av1 haplotype, i.e., they are matched in the classical class I $(R T 1-A)$, but not the class II $(R T 1-B / D)$ and non-classical class I ( RT1-CE/N/M) $\mathrm{MHC}$ regions (cf. Table 1). The strains are matched for minor histocompatibility antigens as both express the same class III MHC genes on the PVG genetic background. Disparity for either the class II locus $R T 1-B / D$ or non-MHC genes elicits fatal GvHD in the rat, while the class I loci $R T 1-A$ and $R T 1-C E / N / M$, respectively, have little or no effect (Oaks and Cramer, 1985). Therefore, in the [PVG.1U $\rightarrow$ PVG.R23] combination, GvHD is primarily due to the mismatch of class II genes. Dahlke and coworkers (Jäger et al., 2007) have made use of a similar semi-allogeneic transplantation model, where a mismatch only in MHC class II genes induced lethal GvHD in [LEW.AR1 $\rightarrow$ LEW.AR2] transplanted rats. We used PVG.R23 as HCT recipients and PVG.1U rats as marrow donors, respectively, in our experiments (Zinöcker et al., 2012). This model was designed to better mimic a clinical setting where some degree of mismatch of the donor MHC is permissible to perform a HCT procedure on patients in need of a transplant (Petersdorf, 2007). It should not be inferred from this model, however, that it can replicate the setting of haploidentical HCT in humans, where siblings, who share half of their MHC genes and a range of minor histocompatibility antigens with the recipient, serve as stem cell donors. Rather, the semi-compatible rat HCT model reflects a transplantation scenario in which polymorphisms of both MHC and non-MHC genes contribute to the induction of acute GvHD.
The HCT protocols described above (cf. Figure 1) resulted in the onset of a rapid wasting disease with severe loss of weight that was typical of acute GvHD and was fatal in $90-100 \%$ of recipients (Zinöcker et al., 2011a,b, 2012). The kinetics of disease progression were similar in both the MHC mismatched [PVG.7B $\rightarrow \mathrm{BN}$ ] and the partially matched [PVG.1U $\rightarrow$ PVG.R23] model (Zinöcker et al., 2012). The titrated DLI dose required to reproducibly invoke lethal acute GvHD in the latter model $\left(9 \times 10^{6} \mathrm{~T}\right.$ cells from lymph nodes) was higher compared to the former $\left(5 \times 10^{6} \mathrm{~T}\right.$ cells from lymph nodes; Zinöcker et al., 2012). Recipients were monitored closely over time for GvHD-typical symptoms which were quantified using a scoring table (Zinöcker et al., 2011a) adapted from Cooke et al. (1996).

Acute GvHD primarily affects the liver, the intestine and the skin (Ferrara et al., 2008). In our models, severe GvHD symptoms were observed (Zinöcker et al., 2011a). The skin was targeted by GvHR; poor grooming, ruffling, fur loss, skin flaking, and occasionally, skin lesions were manifest. These observations were confirmed histologically, with GvHD symptoms present in the skin (Figure 2) and secondary lymphoid organs, spleen and lymph nodes (Zinöcker et al., 2011a). Histological evaluation of the liver and gastrointestinal tract revealed no significant pathological changes of these organs. Therefore, results from these models pertain primarily to cutaneous GvHD. The absence of observable pathology of the liver and the gut could simply depend on the rapid onset and progression of GvHD in host rats, marked by dehydration and severe weight loss, before histopathology of other organs became manifest. On the other hand, they may reflect significant differences in the underlying mechanisms of disease development affecting distinct target sites in these models.

Despite the considerable genetic barriers in the fully and partially mismatched alloHCT settings, we reproducibly established stable allogeneic rat chimeras by transplanting large numbers of bone marrow cells that were extensively depleted of T cells. These protocols demonstrate the central importance of T cells in GvHD as is the case in humans (Ferrara et al., 2008), and, as defined numbers of donor $\mathrm{T}$ cells were sufficient to subsequently induce severe acute GvHD, these models may serve to investigate the contributions of $\mathrm{T}$ cells and other cell types to GvHR in vivo and to manipulate such alloimmune responses with drugs or different modes of cellular therapy.

One important advantage of using the rat model, which we discuss further in the following section, is the availability of corresponding in vitro models of GvHR, especially the rat skin explant assay. This model resembles key features of clinical GvHR in a simple experimental setting that can be highly standardized and easily manipulated.

\section{THE RAT SKIN EXPLANT ASSAY}

Robust risk estimates of GvHD incidence and severity would allow clinicians to intervene at the stage of donor selection, pre-transplant conditioning, and choice of immunosuppressive treatment in the course of transplantation. It is well established that disparities in minor and major human leukocyte antigens between patients and donors can cause GvHD. A number of human biomarkers of acute and chronic GvHD for prediction of treatment outcome and mortality have been identified recently 


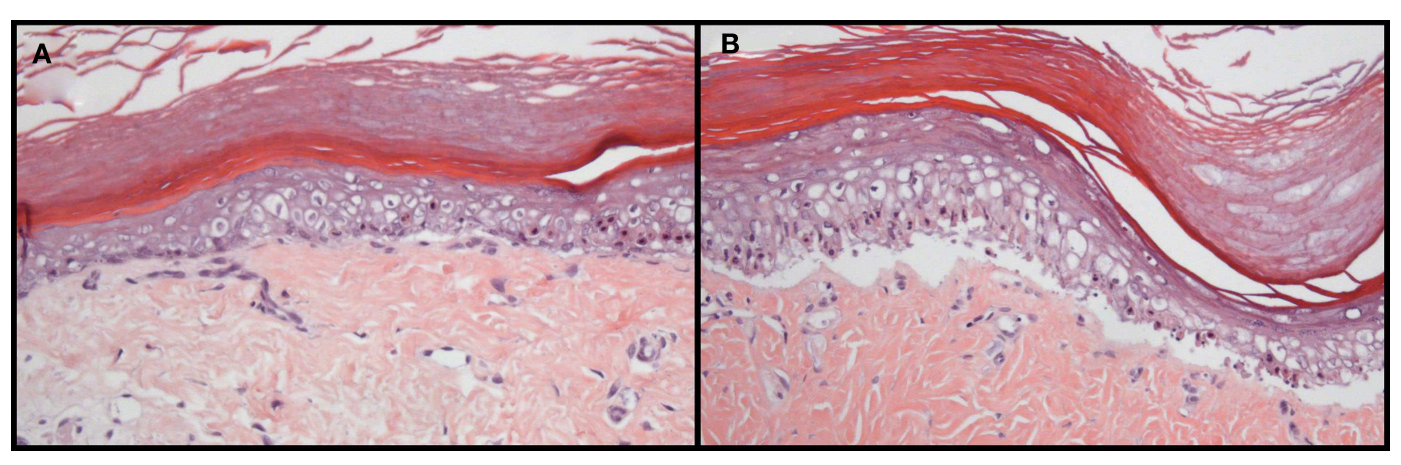

FIGURE 2 | Histopathology of GvHD in rats transplanted with allogeneic, fully MHC mismatched bone marrow. Grade II (A) and III-IV (B) pathology is manifest in the skin of BN rats that suffered from acute GvHD after bone marrow transplantation and donor lymphocyte infusion from PVG donors. Pathological grading was performed based on the GvHD classification originally described by Lerner et al. (1974) for human skin GvHD. Skin was removed from the paws at autopsy and tissue sections were stained with hematoxylin and eosin. These photographs are reprinted from Novota et al. (2008) with permission from the publisher.
(Paczesny et al., 2009; Levine et al., 2012b) and their reliability was prospectively evaluated in patients (Levine et al., 2012a).

The skin explant assay is an in vitro model which can predict GvHD in patients with high sensitivity and specificity. It was prospectively tested as a method to predict GvHD incidence and severity in a donor/patient cohort by Vogelsang et al. (1985). Several studies used the skin explant assay to predict the likelihood of acquiring GvHD and reported correlation rates of $80-90 \%$ with clinical outcome, which proved the skin explant assay superior to other in vitro models that had been designed for this purpose (Sviland and Dickinson, 1999; Dickinson et al., 2001; Hromadnikova et al., 2001; Sviland et al., 2001; Wang et al., 2006). The accuracy of the prediction by skin explant, however, was dependent on the type of GvHD prophylaxis and conditioning regimens used. Matched unrelated donor transplants, including $\mathrm{T}$ cell depletion protocols, gave understandably low prediction rates (Wang et al., 2006).

The skin explant closely resembles the histopathology of cutaneous GvHD and allows the study of pathophysiological processes related to GvHR (Sviland and Dickinson, 1999; Dickinson et al., 2001; Dickinson et al., 2002). Histological grading of the skin explant, from grade I to grade IV with increasing severity (Lerner et al., 1974), represents a standardized method to evaluate the risk for selected donor/recipient combinations before transplantation. One problem for a broad application of the assay in experimental studies is the shortage and genetic heterogeneity of skin biopsies from healthy donors. To overcome this problem and to reduce the need for animal experimentation, we developed a rat skin explant assay that can complement and in part replace transplantations in rodents. This assay can be highly standardized and results are not hampered by undefined genetic differences between tissue samples which cannot be avoided in human studies. The experimental procedure is described in detail elsewhere (Novota et al., 2008). Briefly, lymphocytes from the spleens of donors are stimulated with irradiated lymphocytes from the spleens of recipients in a mixed lymphocyte reaction for 7 days, then transferred to a cultured skin biopsy of the recipient and co-incubated for three more days. The GvHR is then evaluated and scored by histology using the same criteria as for grading GvHR in human skin explants
(Sviland and Dickinson, 1999). Using genetically well-defined inbred strains, we showed that combinations with differences in major histocompatibility antigens usually led to grade III or IV GvHR (Novota et al., 2008). GvHR was on average less severe (grade II) in MHC congenic strain combinations which are only mismatched in minor histocompatibility antigens than in combinations with major or minor plus major histoincompatibility (Novota et al., 2008). The histopathology of cutaneous GvHR in these skin explants closely resembled the histopathology of GvHR in human skin explants (Figure 3). We were also interested to determine whether the rat skin explant assay could resemble, in addition to histological features of GvHD, the molecular profile of GvHD in the patient. In our initial study (Novota et al., 2008), we focused on MHC-linked Hsp70 genes because the expression of stress-inducible heat shock protein 70 has been correlated with the GvHR grading in human skin explants (Jarvis et al., 2003). Indeed, the relative expression of the Hsp70-1 (Hspa1b) and Hsp70-2 (Hspala) genes correlated with the grade of GvHR in rat skin explants (Novota et al., 2008), indicating that certain molecular patterns of GvHR are conserved between human and rat skin explants.

This result encouraged us to use the rat skin explant assay for searching new genetic biomarkers of GvHR. In an expression profiling study with special emphasis on MHC and NK gene complex (NKC) genes, $11 \mathrm{MHC}, 6 \mathrm{NKC}$, and 168 genes in other genomic regions were identified to be regulated during GvHR in rat skin explants (Novota et al., 2011). For MHC and NKC genes, the results were verified by real time PCR experiments on samples from other skin explant assays using different strain combinations, on skin with cutaneous GvHD from transplanted rats, and on samples from human skin explant assays. The genes that were confirmed to be regulated also in human skin explant samples with GvHR included TAP1, PSMB8, C2, UBD, and OLR1 (Novota et al., 2011). These genes have known polymorphisms in humans and are therefore potential candidates for diagnostic biomarkers in the clinic.

The rat skin explant assay is a promising tool not only for the identification of candidate genes regulated in GvHR but also for 


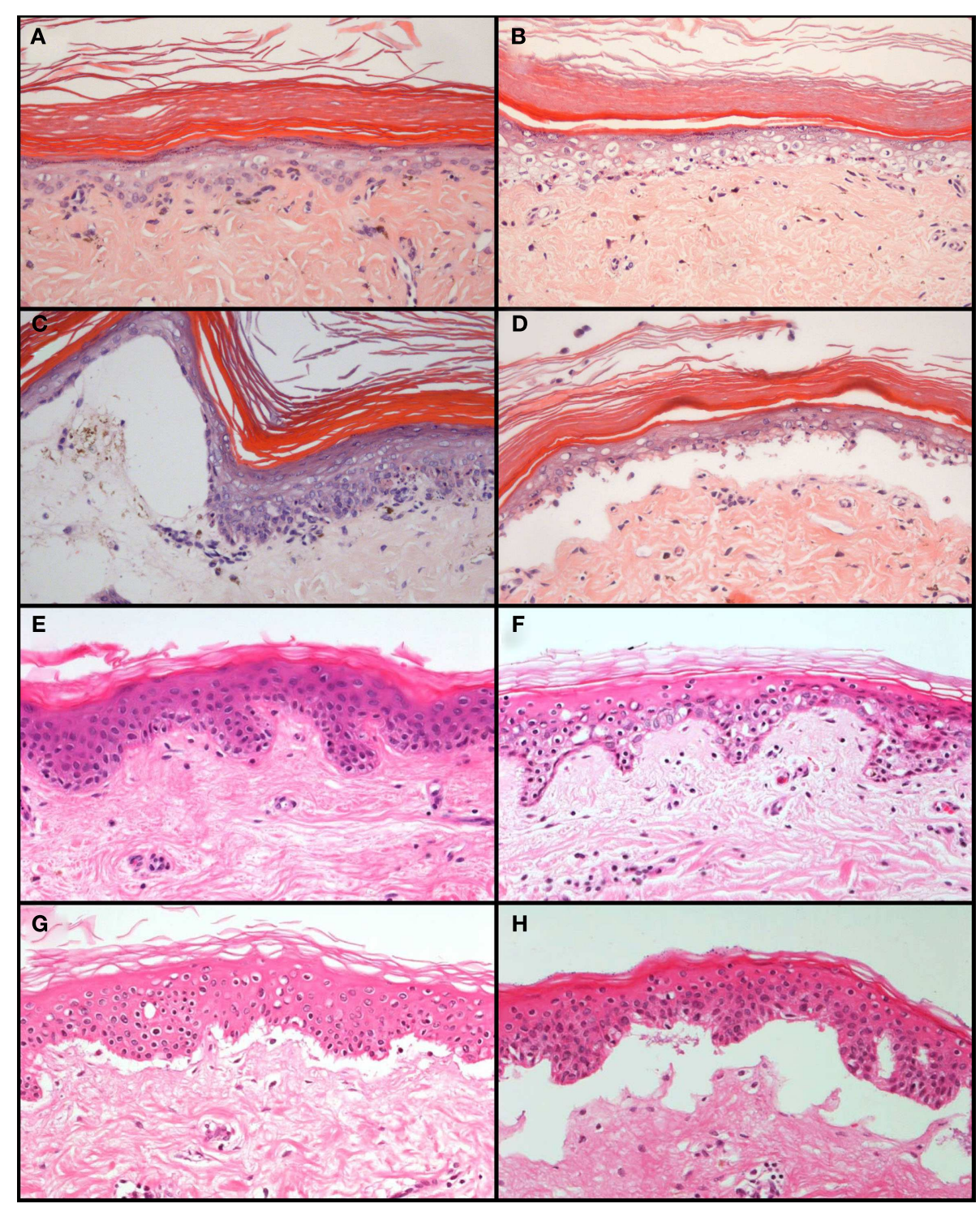

FIGURE 3 | Comparison of the histopathology of GvHR in human skin explants and rat skin explants. GvHR of increasing severity occur during co-incubation of pre-stimulated, allogeneic lymphocytes with explants of rat skin (A-D) or human skin biopsies (E-H). Grade I [mild vacuolization of epidermal cells with occasional dyskeratotic bodies; $(\mathbf{A}, \mathbf{E})$ ], grade II [diffuse vacuolization of basal cells with

the functional evaluation of GvHR in an experimental system. As with the human skin explant assay, it can be used to investigate the role of cytokines (Dickinson et al., 1991; Dickinson et al., 2002; Wang et al., 2002) and innate immunity in GvHR, e.g., heat-shock protein 70 (Jarvis et al., 2002, 2003), the roles of NK cells, dendritic cells (Wilson et al., 2009), regulatory T cells (Wang et al., 2009; Mavin et al., 2012), and subsets of T cells (Dickinson et al., 2002) as well as Fas expression (Ruffin et al., 2011).

\section{CONCLUSION}

The laboratory rat is a useful biological model organism for the study of alloHCT, immune reconstitution, and transplant-related scattered dyskeratotic bodies; $(\mathbf{B}, \mathbf{F})$ ], grade III [formation of subepidermal clefts; $(\mathbf{C}, \mathbf{G})$ ], and grade IV [complete separation of the epidermis from the dermis; $(\mathbf{D}, \mathbf{H})$ ] pathological changes are similar in human and rat skin explants. The photographs of the rat skin explants depicted in (A-D) were reprinted from Novota et al. (2008) with permission from the publisher.

complications. While the mouse has found its place in the limelight of comparative and translational immunology, a steadily increasing number of insightful investigations in the rat have been undertaken. When compared to mice and other animal models, experiments in rats can add instrumental insights into the consistency or divergence of findings made in related mammalian species. We found that after transplantation, host rats reconstituted peripheral regulatory $\mathrm{T}$ cells of host but not donor origin, and were deficient of any such cells when suffering from severe acute GvHD.

Important aspects of alloHCT, such as GvHR and tolerance mechanisms that are highly relevant for immune reconstitution 
can now be addressed ex vivo in the rat skin explant model. Therefore, this assay represents a valuable and accessible research tool that complements the in vivo model. These research tools currently available in the rat model might also prove to be important for other areas of research.

\section{REFERENCES}

Aksu, A. E., Horibe, E., Sacks, J., Ikeguchi, R., Breitinger, J., Scozio, M., et al. (2008). Co-infusion of donor bone marrow with host mesenchymal stem cells treats GVHD and promotes vascularized skin allograft survival in rats. Clin. Immunol. 127, 348-358.

Anderson, B. E., McNiff, J., Yan, J., Doyle, H., Mamula, M., Shlomchik, M. J., et al. (2003). Memory CD4 ${ }^{+}$ $\mathrm{T}$ cells do not induce graft-versushost disease. J. Clin. Investig. 112, 101-108.

Anderson, B. E., McNiff, J. M., Matte, C., Athanasiadis, I., Shlomchik, W. D., and Shlomchik, M. J. (2004). Recipient $\mathrm{CD}^{+} \mathrm{T}$ cells that survive irradiation regulate chronic graft-versus-host disease. Blood 104, 1565-1573.

Andrews, D. M., Sullivan, L. C., Baschuk, N., Chan, C. J., Berry, R., Cotterell, C. L., et al. (2012). Recognition of the nonclassical MHC class I molecule H2-M3 by the receptor Ly49A regulates the licensing and activation of NK cells. Nat. Immunol. 13, 1171-1177.

Appelbaum, F. R. (2001). Haematopoietic cell transplantation as immunotherapy. Nature 411, 385-389.

Bernard, I., Fournie, G. J., and Saoudi, A. (2010). Genomics studies of immune-mediated diseases using the BN-LEW rat model. Methods Mol. Biol. 597, 389-402.

Beyersdorf, N., Gaupp, S., Balbach, K., Schmidt, J., Toyka, K. V., Lin, C.H., et al. (2005). Selective targeting of regulatory $\mathrm{T}$ cells with CD28 superagonists allows effective therapy of experimental autoimmune encephalomyelitis. J. Exp. Med. 202, 445-455.

Bosch, M., Khan, F. M., and Storek, J. (2012). Immune reconstitution after hematopoietic cell transplantation. Curr. Opin. Hematol. 19, 324-335.

Brenan, M., and Puklavec, M. (1992). The MRC OX-62 antigen: a useful marker in the purification of rat veiled cells with the biochemical properties of an integrin. J. Exp. Med. 175, 1457-1465.

Brideau, R. J., Carter, P. B., McMaster, W. R., Mason, D. W., and Williams, A. F. (1980). Two subsets of rat
T lymphocytes defined with monoclonal antibodies. Eur. J. Immunol. 10, 609-615.

Brunstein, C. G., Miller, J. S., Cao, Q., McKenna, D. H., Hippen, K. L., Curtsinger, J., et al. (2011). Infusion of ex vivo expanded $T$ regulatory cells in adults transplanted with umbilical cord blood: safety profile and detection kinetics. Blood 117, 1061-1070.

Castro, M. A., Nunes, R. J., Oliveira, M. I., Tavares, P. A., Simoes, C., Parnes, J. R. et al. (2003). OX52 is the rat homologue of CD6: evidence for an effector function in the regulation of CD5 phosphorylation. J. Leukoc. Biol. 73, 183-190.

Chambers, W. H., Brumfield, A. M., Hanley-Yanez, K., Lakomy, R., Herberman, R. B., McCaslin, D. C. et al. (1992). Functional heterogeneity between NKR-P1 $1^{\text {bright } / L y c o p e r s i c o n ~}$ esculentum lectin (L.E.) bright $^{\text {and }}$ NKR-P1 $1^{\text {bright }} /$ L.E. ${ }^{\text {dim }}$ subpopulations of rat natural killer cells. J. Immunol. 148, 3658-3665.

Chen, B. J., Cui, X., Sempowski, G. D., Liu, C., and Chao, N. J. (2004). Transfer of allogeneic $\mathrm{CD}_{62} \mathrm{~L}^{-}$memory $\mathrm{T}$ cells without graft-versus-host disease. Blood 103, 1534-1541.

Clancy, J. Jr., Chan, P., and Schurath, R. (1976). ${ }^{3} \mathrm{H}$-deoxythymidine incorporation in graft-versus-host disease in the Norway rat. II. Autoradiographic studies. Virchows. Arch. B Cell Pathol. 22, 341-352.

Clancy, J. Jr., Mauser, L., and Chapman, A. L. (1983). Level and temporal pattern of naturally cytolytic cells during acute graft-versus-host disease 79, 1-10.

Cohen, J. L., Trenado, A., Vasey, D., Klatzmann, D., and Salomon, B. L. (2002). CD4(+)CD25(+) immunoregulatory $\mathrm{T}$ Cells: new therapeutics for graft-versushost disease. J. Exp. Med. 196, 401-406.

Cooke, K. R., Kobzik, L., Martin, T. R., Brewer, J., Delmonte, J. Jr., Crawford, J. M., et al. (1996). An experimental model of idiopathic pneumonia syndrome after bone marrow transplantation: I. The roles of minor $\mathrm{H}$ antigens and endotoxin. Blood 88, 3230-3239.

Dallman, M. J., Thomas, M. L., and Green, J. R. (1984). MRC (GVHD) in the rat. Cell. Immunol.

\section{ACKNOWLEDGMENTS}

We thank Dr. A. Neil Barclay for help with the definition of rat leukocyte phenotypes. This work was supported by the grants MRTN-CT-2004-512253 (TRANS-NET) and FP7-PEOPLE2012-ITN-315963 (CELLEUROPE) from the European Union.

OX-19: a monoclonal antibody that labels rat $\mathrm{T}$ lymphocytes and augments in vitro proliferative responses. Eur. J. Immunol. 14 260-267.

Di Ianni, M., Falzetti, F., Carotti, A., Terenzi, A., Castellino, F., Bonifacio, E., et al. (2011). Tregs prevent GVHD and promote immune reconstitution in HLA-haploidentical transplantation. Blood 117, 3921-3928.

Dickinson, A. M., Cavet, J., Cullup, H. Wang, X. N., Sviland, L., and Middleton, P. G. (2001). GvHD risk assessment in hematopoietic stem cell transplantation: role of cytokine gene polymorphisms and an in vitro human skin explant model. Hum. Immunol. 62, 1266-1276.

Dickinson, A. M., Sviland, L., Dunn, J., Carey, P., and Proctor, S. J. (1991). Demonstration of direct involvement of cytokines in graft-versus-host reactions using an in vitro human skin explant model. Bone Marrow Transplant. 7, 209-2016.

Dickinson, A. M., Wang, X.-N., Sviland, L., Vyth-Dreese, F. A., Jackson, G. H., Schumacher, T. N. M., et al. (2002). In situ dissection of the graft-versus-host activities of cytotoxic T cells specific for minor histocompatibility antigens. Nat. Med. 8, 410-414.

Dijkstra, C. D., Dopp, E. A., Joling, P., and Kraal, G. (1985). The heterogeneity of mononuclear phagocytes in lymphoid organs: distinct macrophage subpopulations in the rat recognized by monoclonal antibodies ED1, ED2 and ED3. Immunology 54, 589-599.

Dorshkind, K., Montecino-Rodriguez, E., and Signer, R. A. (2009). The ageing immune system: is it ever too old to become young again? Nat. Rev. Immunol. 9, 57-62.

Edinger, M., Hoffmann, P., Ermann, J., Drago, K., Fathman, C. G., Strober, S., et al. (2003). CD $4^{+} \mathrm{CD} 25^{+}$ regulatory $\mathrm{T}$ cells preserve graftversus-tumor activity while inhibiting graft-versus-host disease after bone marrow transplantation. Nat. Med. 9, 1144-1150.

Engh, E., Strøm-Gundersen, I., Benestad, H. B., and Rolstad, B. (2001). Long-term donor chimerism after MHC (RT1) mismatched bone marrow transplantation in the rat: the role of host alloreactive NK cells.
Scand. J. Immunol. 54, 198-203.

Ferrara, J. L. M., Levine, J. E., Reddy, P., and Holler, E. (2008). Graft-versushost disease. Lancet 373, 1550-1561.

Fidler, J. M., Chang, T. Q., Bauer, R., Young, J. D., and Vitt, C. R. (1993). Suppression of graft-versushost disease by succinyl acetone in a rat allogeneic bone marrow transplantation model. Transplantation 55, 367-373.

Foster, R. D., Ascher, N. L., McCalmont, T. H., Neipp, M., Anthony, J. P., and Mathes, S. J. (2001). Mixed allogeneic chimerism as a reliable model for composite tissue allograft tolerance induction across major and minor histocompatibility barriers. Transplantation 72, 791-797.

Fukumoto, T., McMaster, W. R., and Williams, A. F. (1982). Mouse monoclonal antibodies against rat major histocompatibility antigens. Two Ia antigens and expression of Ia and class I antigens in rat thymus. Eur. J. Immunol. 12, 237-243.

Geddes, M., and Storek, J. (2007). Immune reconstitution following hematopoietic stem-cell transplantation. Best Pract. Res. Clin. Haematol. 20, 329-348.

Goral, J., Mathews, H. L., and Clancy, J. Jr. (1995). Antibodies specific for the $70-\mathrm{kDa}$ heat-shock protein parallel the development of acute graft-versus-host disease in (DA x LEW)F1 rats. Clin. Immunol. Immunopathol. 75, 147-153.

Goral, J., Mathews, H. L., and Clancy, J. Jr. (1998). Expression of 70$\mathrm{kDa}$ heat-shock protein during acute graft-versus-host disease. Clin. Immunol. Immunopathol. 86, 252-258.

Goral, J., Shenoy, S., Mohanakumar, T., and Clancy, J. Jr. (2002). Antibodies to $70 \mathrm{kD}$ and $90 \mathrm{kD}$ heat shock proteins are associated with graft-versus-host disease in peripheral blood stem cell transplant recipients. Clin. Exp. Immunol. 127, 553-559.

Gowing, H., Braakman, E., Hagenbeek, A., Lawler, M., McCann, S. R., Pamphilon, D. H., et al. (1998). Influence of ultraviolet-B irradiation on engraftment, graft-versus-host disease and graft-versus-leukemia effect in a rat model for allogeneic bone marrow transplantation. Bone Marrow Transplant. 21, 801-807. 
Han, G., Shao, H., Peng, Y., Zhang, P., Ke, Y., Kaplan, H. J., et al. (2007). Suppressor role of rat $\mathrm{CD} 8^{+}$ CD45RC ${ }^{\text {low }} \mathrm{T}$ cells in experimental autoimmune uveitis (EAU). $J$. Neuroimmunol. 183, 81-88.

Hoffmann, P., Ermann, J., Edinger, M., Fathman, C. G., and Strober, S. (2002). Donor-type $\mathrm{CD} 4(+) \mathrm{CD} 25(+)$ regulatory $\mathrm{T}$ cells suppress lethal acute graft-versushost disease after allogeneic bone marrow transplantation. J. Exp. Med. 196, 389-399.

Holland, A. M., Zakrzewski, J. L., Goldberg, G. L., Ghosh, A., and van den Brink, M. R. (2008). Adoptive precursor cell therapy to enhance immune reconstitution after hematopoietic stem cell transplantation in mouse and man. Semin. Immunopathol. 30, 479-487.

Hromadnikova, I., Sedlacek, P., Stary, J., Cermakova, M., Vavrinec, J., Stechova, K., et al. (2001). An in vitro skin explant assay as a predictive assay for graft-versus-host disease in a cohort of pediatric transplants. Pediatr. Transplant. 5, 258-265.

Huang, G., Ashton, C., Kumbhani, D. S., and Ying, Q.-L. (2011). Genetic manipulations in the rat: progress and prospects. Curr. Opin. Nephrol. Hypertens. 20, 391-399.

Hünig, T., Wallny, H. J., Hartley, J. K., Lawetzky, A., and Tiefenthaler, G. (1989). A monoclonal antibody to a constant determinant of the rat $\mathrm{T}$ cell antigen receptor that induces $T$ cell activation. Differential reactivity with subsets of immature and mature T lymphocytes. J. Exp. Med. 169, 73-86.

Itakura, S., Asari, S., Rawson, J., Ito, T., Todorov, I., Liu, C. P., et al. (2007). Mesenchymal stem cells facilitate the induction of mixed hematopoietic chimerism and islet allograft tolerance without GVHD in the rat. Am. J. Transplant. 7, 336-346.

Jäger, M. D., Liu, J. Y., Timrott, K. F., Popp, F. C., Stöltzing, O., Lang, S. A., et al. (2007). Sirolimus promotes tolerance for donor and recipient antigens after MHC class II disparate bone marrow transplantation in rats. Exp. Hematol. 35, 164-170.

Jarvis, M., Marzolini, M., Wang, X.-N., Jackson, G., Sviland, L., and Dickinson, A. M. (2003). Heat shock protein 70: correlation of expression with degree of graft-versushost response and clinical graftversus-host disease. Transplantation $76,849-853$.

Jarvis, M., Schulz, U., Dickinson, A. M., Sviland, L., Jackson, G., Konur, A., et al. (2002). The detection of apoptosis in a human in vitro skin explant assay for graft versus host reactions. J. Clin. Pathol. 55, 127-132.

Jefferies, W. A., Green, J. R., and Williams, A. F. (1985). Authentic T helper CD4 (W3/25) antigen on rat peritoneal macrophages. J. Exp. Med. 162, 117-127.

Kampinga, J., Kroese, F. G. M., Pol, G. H., Opstelten, D., Seijen, H. G., Boot, J. H. A., et al. (1990). RT7-defined alloantigens in rats are part of the leucocyte common antigen Family. Scand. J. Immunol. 31, 699-710.

Kelley, J., Walter, L., and Trowsdale, J. (2005a). Comparative genomics of major histocompatibility complexes. Immunogenetics 56, 683-695.

Kelley, J., Walter, L., and Trowsdale, J. (2005b). Comparative genomics of natural killer cell receptor gene clusters. PLoS Genet. 1, 129-139. doi:10.1371/journal.pgen.0010027

Kimura, T., Enosawa, S., Kamada, N., Kobayashi, E., Toyama, N., Doy, M., et al. (1995). Evidence that the elevation of soluble MHC class I antigens in the serum precedes the onset of graft-versus-host disease and is correlated with the severity of the disease in rats. Transpl. Immunol. 3 , 299-304.

Kitazawa, Y., Li, X.-K., Liu, Z., Kimura, H., Isaka, Y., Hünig, T., et al. (2010). Prevention of graft-versus-host diseases by in vivo supCD28mAbexpanded antigen-specific nTreg cells. Cell Transplant. 19, 765-774.

Kitazawa, Y., Li, X.-K., Xie, L., Zhu, P., Kimura, H., and Takahara, S. (2012). Bone marrow-derived conventional, but not cloned, mesenchymal stem cells suppress lymphocyte proliferation and prevent graft-versus-host disease in rats. Cell Transplant. 21, 581-590.

Klimczak, A., Unal, S., Jankowska, A., Coburn, C., and Siemionow, M. (2007). Donor-origin cell engraftment after intraosseous or intravenous bone marrow transplantation in a rat model. Bone Marrow Transplant. 40, 373-380.

Kobayashi, E., Enosawa, S., Fujimura, A., Kamada, N., and Suzuki, S. (1998). Timing of lymphocyte transfusion and portal clamping for the development of lethal graft-versus-host disease in the rat. Surg. Today 28 , 1036-1041.

Kolb, H.-J. (2008). Graft-versusleukemia effects of transplantation and donor lymphocytes. Blood 112, 4371-4383.

Korngold, R., and Sprent, J. (1987). Variable capacity of $\mathrm{L}_{3} \mathrm{~T}_{4}{ }^{+} \mathrm{T}$ cells to cause lethal graft-versus-host disease across minor histocompatibility barriers in mice. J. Exp. Med. 165 1552-1564.

Krenger, W., Blazar, B. R., and Holländer, G. A. (2011). Thymic T-cell development in allogeneic stem cell transplantation. Blood 117, 6768-6776.

Krenger, W., and Holländer, G. (2008). The immunopathology of thymic GVHD. Semin. Immunopathol. 30, 439-456.

Kühnlein, P., Park, J. H., Herrmann, T., Elbe, A., and Hünig, T. (1994). Identification and characterization of rat gamma/delta $\mathrm{T}$ lymphocytes in peripheral lymphoid organs, small intestine, and skin with a monoclonal antibody to a constant determinant of the gamma/delta $\mathrm{T}$ cell receptor. J. Immunol. 153, 979-986.

Kveberg, L., Jiménez-Royo, P., Naper, C., Rolstad, B., Butcher, G. W., Vaage, J. T., et al. (2010). Two complementary rat NK cell subsets, Ly49s3 ${ }^{+}$ and NKR-P1B ${ }^{+}$, differ in phenotypic characteristics and responsiveness to cytokines. J. Leukoc. Biol. 88 87-93.

Lerner, K. G., Kao, G. F., Storb, R., Buckner, C. D., Clift, R. A., and Thomas, E. D. (1974). Histopathology of graftvs.-host reaction (GvHR) in human recipients of marrow from HL-Amatched sibling donors. Transplant. Proc. 6, 367-371.

Leventhal, J., Huang, Y., Xu, H., Goode, I., and Ildstad, S. (2012). Novel regulatory therapies for prevention of graft-versus-host disease. BMCMed. 10, 48. doi:10.1186/1741-7015-1048

Levine, J. E., Logan, B. R., Wu, J., Alousi, A. M., Bolanos-Meade, J., Ferrara, J. L., et al. (2012a). Acute graft-versushost disease biomarkers measured during therapy can predict treatment outcomes: a Blood and Marrow Transplant Clinical Trials Network study. Blood 119, 3854-3860.

Levine, J. E., Paczesny, S., and Sarantopoulos, S. (2012b). Clinical applications for biomarkers of acute and chronic graft-versus-host disease. Biol. Blood Marrow Transplant. 18, S116-S124.

Lin, J. Y., Tsai, F. C., Wallace, C. G., Huang, W. C., Wei, F. C. and Liao, S. K. (2012). Optimizing chimerism level through bone marrow transplantation and irradiation to induce long-term tolerance to composite tissue allotransplantation. J. Surg. Res. 178, 487-493. doi:10.1016/j.jss.2012.02.064

Løvik, G., Vaage, J. T., Naper, C., Benestad, H. B., and Rolstad, B. (1995).
Recruitment of alloreactive natural killer cells to the rat peritoneum by a transfected cell line secreting rat recombinant interleukin2. J. Immunol. Methods 179, 59-69.

Maeda, K., Sato, T., Azuma, M., Yagita, H., and Okumura, K. (1997). Characterization of rat CD80 and CD86 by molecular cloning and $\mathrm{mAb}$. Int . Immunol. 9, 993-1000.

Magenau, J. M., Qin, X., Tawara, I., Rogers, C. E., Kitko, C., Schlough, M., et al. (2010). Frequency of CD4(+)CD25(hi)FOXP3(+) regulatory $\mathrm{T}$ cells has diagnostic and prognostic value as a biomarker for acute graft-versus-host-disease. Biol. Blood Marrow Transplant. 16, 907-914.

Martens, A. C., van Bekkum, D. W., and Hagenbeek, A. (1990). The BN acute myelocytic leukemia (BNML) (a rat model for studying human acute myelocytic leukemia (AML)). Leukemia 4, 241-257.

Mavin, E., Ahmed, S. S., O'Boyle, G., Turner, B., Douglass, S., Norden, J., et al. (2012). Regulatory T cells inhibit $\mathrm{CD}^{+}$T-cell tissue invasion in human skin graft-versushost reactions. Transplantation 94 , 456-464.

McMaster, W. R., and Williams, A. F. (1979). Identification of Ia glycoproteins in rat thymus and purification from rat spleen. Eur. J. Immunol. 9, 426-433.

Miura, Y., Thoburn, C. J., Bright, E. C., Phelps, M. L., Shin, T., Matsui, E. C., et al. (2004). Association of Foxp3 regulatory gene expression with graft-versus-host disease. Blood 104, 2187-2193.

Mrowka, C., Thoenes, G. H., Langer, K. H., and Bartlett, R. R. (1994). Prevention of the acute graftversus-host disease (GVHD) in rats by the immunomodulating drug leflunomide. Ann. Hematol. 68, 195-199.

Na, H. R., Hiserødt, J. C., and Seelig, L. L. Jr. (1992). Distribution of lymphocyte subsets in rat milk from normal and Trichinella spiralisinfected rats. J. Reprod. Immunol. 22, 269-279.

Naper, C., Dai, K.-Z., Kveberg, L., Rolstad, B., Niemi, E. C., Vaage, J. T., et al. (2005). Two structurally related rat Ly49 receptors with opposing functions (Ly49 stimulatory receptor 5 and Ly49 inhibitory receptor 5) recognize nonclassical MHC class Ibencoded target ligands. J. Immunol. $174,2702-2711$.

Naper, C., Hayashi, S., Kveberg, L., Niemi, E. C., Lanier, L. L., Vaage, J. 
T., et al. (2002). Ly-49s3 is a promiscuous activating rat NK cell receptor for nonclassical MHC class Iencoded target ligands. J. Immunol. $169,22-30$.

Naper, C., Kveberg, L., Engh, E., Nestvold, J., Rolstad, B., and Vaage, J. T. (2010). Partial NK cell tolerance induced by radioresistant host cells in rats transplanted with MHC-mismatched bone marrow. Int. Immunol. 22, 973-980.

Nestvold, J. M., Omdal, B. K., Dai, K.-Z., Martens, A., Benestad, H. B., Vaage, J. T., et al. (2008). A second prophylactic MHC-mismatched bone marrow transplantation protects against rat acute myeloid leukemia (BNML) without lethal graft-versushost disease. Transplantation 85, 102-111.

Nicolls, M. R., Aversa, G. G., Pearce, N. W., Spinelli, A., Berger, M. F., Gurley, K. E., et al. (1993). Induction of long-term specific tolerance to allografts in rats by therapy with an anti-CD3-like monoclonal antibody. Transplantation 55, 459-468.

Novota, P., Sviland, L., Zinöcker, S., Stocki, P., Balavarca, Y., Bickeböller, H., et al. (2008). Correlation of Hsp70-1 and Hsp70-2 gene expression with the degree of graftversus-host reaction in a rat skin explant model. Transplantation 85, 1809-1816.

Novota, P., Zinöcker, S., Norden, J., Wang, X. N., Sviland, L., Opitz, L., et al. (2011). Expression profiling of major histocompatibility and natural killer complex genes reveals candidates for controlling risk of graft versus host disease. PLoS ONE 6, el6582. doi:10.1371/journal.pone.0016582

Oaks, M. K., and Cramer, D. V. (1985). The genetics of bone marrow transplantation in the rat. Transplantation $39,69-76$.

Ohajekwe, O. A., Hardy, M. A., and Oluwole, S. F. (1995). Prevention of graft-versus-host disease and the induction of transplant tolerance by low-dose UV-B irradiation of BM cells combined with cyclosporine immunosuppression. Transplantation 60, 1510-1516.

Okayama, J., Ko, S., Kanehiro, H., Kanokogi, H., Hisanaga, M., Ohashi, $\mathrm{K}$, et al. (2004). Bone marrow chimerism and tolerance induced by single-dose cyclophosphamide. $J$. Surg. Res. 120, 102-110.

Okayama, J., Ko, S., Kanehiro, H., Kanokogi, H., and Nakajima, Y. (2006). Efficacy of transient treatment with FK506 in the early phase on cyclophosphamide-induced bone marrow chimerism and transplant tolerance across MHC barriers. J. Surg. Res. 133, 61-68.

Paczesny, S., Choi, S. W., and Ferrara, J. L. (2009). Acute graft-versus-host disease: new treatment strategies. Curr. Opin. Hematol. 16, 427-436.

Pakkala, I., Taskinen, E., Pakkala, S., and Raisanen-Sokolowski, A. (2001). MC1288, a vitamin D ana$\log$, prevents acute graft-versus-host disease in rat bone marrow transplantation. Bone Marrow Transplant. $27,863-867$.

Paterson, D. J., Jefferies, W. A., Green, J. R., Brandon, M. R., Corthesy, P., Puklavec, M., et al. (1987). Antigens of activated rat $\mathrm{T}$ lymphocytes including a molecule of 50,000 $\mathrm{Mr}$ detected only on $\mathrm{CD} 4$ positive T blasts. Mol. Immunol. 24, 1281-1290.

Peszkowski, M. J., Fujiwara, K., Warfvinge, G., and Larsson, A. (1996). Experimental graft versus host disease in the $(\mathrm{BN} \times \mathrm{LEW}) \mathrm{F} 1$ rat hybrid: an immunohistochemical study of early disease in oral mucosa. Oral. Dis. 2, 2-10.

Petersdorf, E. W. (2007). Risk assessment in haematopoietic stem cell transplantation: histocompatibility. Best Pract. Res. Clin. Haematol. 20, 155-170.

Powrie, F., and Mason, D. (1990). OX$22^{\text {high }} \mathrm{CD}^{+} \mathrm{T}$ cells induce wasting disease with multiple organ pathology: prevention by the OX$22^{\text {low }}$ subset. J. Exp. Med. 172, 1701-1708.

Puklavec, M. J., and Barclay, A. N. (2001). Monoclonal antibodies to rat leukocyte surface antigens, MHC antigens, and immunoglobulins. Curr. Protoc. Immunol. 31, A.4C.1-A.4C.12

Rat Genome Sequencing Project Consortium. (2004). The genome sequence of the Brown Norway rat yields insights into mammalian evolution. Nature 428, 493-521.

Renkonen, R. (1986). Bone marrow transplantation in the rat: V. Lymphoid cell subclasses in the target organs during acute graft-versushost disease. Transplantation 41, 704-708.

Renkonen, R., Wangel, A., and Hayry, P. (1986). Bone marrow transplantation in the rat. B lymphocyte activation in acute graft-versushost disease. Transplantation 41, 290-296.

Rieger, K., Loddenkemper, C., Maul, J., Fietz, T., Wolff, D., Terpe, H., et al. (2006). Mucosal FOXP3 ${ }^{+}$regulatory $\mathrm{T}$ cells are numerically deficient in acute and chronic GvHD. Blood 107, 1717-1723.

Robinson, A. P., White, T. M., and Mason, D. W. (1986). Macrophage heterogeneity in the rat as delineated by two monoclonal antibodies MRC OX-41 and MRC OX-42, the latter recognizing complement receptor type 3. Immunology 57, 239-247.

Rolstad, B. (1985). The popliteal lymph node graft-versus-host $(\mathrm{GvH})$ reaction in the rat: a useful model for studying cell interactions in the immune response? Immunol. Rev. $88,153-168$.

Ruffin, N., Ahmed, S. S., Osorio, L. M., Wang, X.-N., Jackson, G. H., Collin, M. P., et al. (2011). The involvement of epithelial Fas in a human model of graft versus host disease. Transplantation 91, 946-951.

Ruggeri, L., Capanni, M., Urbani, E., Perruccio, K., Shlomchik, W. D., Tosti, A., et al. (2002). Effectiveness of donor natural killer cell alloreactivity in mismatched hematopoietic transplants. Science 295, 2097-2100.

Sadeghi, B., Aghdami, N., Hassan, Z., Forouzanfar, M., Rozell, B., AbediValugerdi, M., et al. (2008). GVHD after chemotherapy conditioning in allogeneic transplanted mice. Bone Marrow Transplant. 42, 807-818.

Santos, G. W., and Owens, A. H. Jr. (1966). Production of graft-versushost disease in the rat and its treatment with cytotoxic agents. Nature 210, 139-140.

Santos, G. W., and Owens, A. H. Jr. (1969). Allogeneic marrow transplants in cyclophosphamide treated mice. Transplant. Proc. 1 , $44-46$.

Sasatomi, K., Sakisaka, S., Kawaguchi, T., Hanada, S., Taniguchi, E., Koga, H., et al. (2005). Cholestasis in a rat model of graft-versus-host disease is accompanied by alteration of the expression and distribution of tightjunction-associated proteins. Int. J. Mol. Med. 15, 431-436.

Savani, B. N., Griffith, M. L., Jagasia, S., and Lee, S. J. (2011). How I treat late effects in adults after allogeneic stem cell transplantation. Blood 117, 3002-3009.

Schroeder, M. A., and DiPersio, J. F. (2011). Mouse models of graftversus-host disease: advances and limitations. Dis. Model. Mech. 4 318-333.

Seddon, B., Saoudi, A., Nicholson, M., and Mason, D. (1996). CD4 ${ }^{+} \mathrm{CD} 8^{-}$ thymocytes that express L-selectin protect rats from diabetes upon adoptive transfer. Eur. J. Immunol. 26, 2702-2708.
Seggewiss, R., and Einsele, $\mathrm{H}$. (2010). Immune reconstitution after allogeneic transplantation and expanding options for immunomodulation: an update. Blood 115, 3861-3868.

Shimabukuro-Vornhagen, A., Hallek, M. J., Storb, R. F., and von BergweltBaildon, M. S. (2009). The role of $B$ cells in the pathogenesis of graft-versus-host disease. Blood 114, 4919-4927.

Shimizu, Y., Goto, S., Vari, F., Lord, R., Edwards-Smith, C., Chiba, S., et al. (1997). The prevention of graftversus-host disease by the serum of liver retransplanted rats. Transpl. Immunol. 5, 67-69.

Shono, Y., Ueha, S., Wang, Y., Abe, J., Kurachi, M., Matsuno, Y., et al. (2010). Bone marrow graft-versushost disease: early destruction of hematopoietic niche after MHCmismatched hematopoietic stem cell transplantation. Blood 115, 5401-5411.

Socié, G., and Blazar, B. R. (2009). Acute graft-versus-host disease: from the bench to the bedside. Blood 114, 4327-4336.

Spickett, G. P., Brandon, M. R., Mason, D. W., Williams, A. F., and Woollett, G. R. (1983). MRC OX-22, a monoclonal antibody that labels a new subset of $\mathrm{T}$ lymphocytes and reacts with the high molecular weight form of the leukocyte-common antigen. $J$. Exp. Med. 158, 795-810.

Stephens, L. A., and Mason, D. (2000). $\mathrm{CD}_{2} 5^{+}$is a marker for $\mathrm{CD} 4^{+}$ thymocytes that prevent autoimmune diabetes in rats, but peripheral $\mathrm{T}$ cells with this function are found in both $\mathrm{CD} 25^{+}$and $\mathrm{CD} 25^{-}$ subpopulations. J. Immunol. 165, 3105-3110.

Storb, R., and Thomas, E. D. (1985). Graft-versus-host disease in dog and man: the Seattle experience. Immunol. Rev. 88, 215-238.

Storek, J. (2008). Immunological reconstitution after hematopoietic cell transplantation - its relation to the contents of the graft. Expert Opin. Biol. Ther. 8, 583-597.

Storek, J., Geddes, M., Khan, F., Huard, B., Helg, C., Chalandon, Y., et al. (2008). Reconstitution of the immune system after hematopoietic stem cell transplantation in humans. Semin. Immunopathol. 30, 425-437.

Sunderland, C. A., McMaster, W. R., and Williams, A. F. (1979). Purification with monoclonal antibody of a predominant leukocyte-common antigen and glycoprotein from rat thymocytes. Eur. J. Immunol. 9, 155-159. 
Sviland, L., and Dickinson, A. M. (1999). A human skin explant model for predicting graft-versushost disease following bone marrow transplantation. J. Clin. Pathol. 52, 910-913.

Sviland, L., Hromadnikova, I., Sedlacek, P., Cermakova, M., Stechova, K., Holler, E., et al. (2001). Histological correlation between different centers using the skin explant model to predict graft-versus-host disease following bone marrow transplantation. Hum. Immunol. 62, 1277-1281.

Taylor, P. A., Lees, C. J., and Blazar, B. R. (2002). The infusion of ex vivo activated and expanded $\mathrm{CD} 4(+) \mathrm{CD} 25(+)$ immune regulatory cells inhibits graft-versushost disease lethality. Blood 99, 3493-3499.

Toubert, A., Glauzy, S., Douay, C., and Clave, E. (2012). Thymus and immune reconstitution after allogeneic hematopoietic stem cell transplantation in humans: never say never again. Tissue Antigens 79, 83-89.

Tournade, H., Pelletier, L., Pasquier, R., Vial, M. C., Mandet, C., and Druet, P. (1990). Graft-versus-host reactions in the rat mimic toxin-induced autoimmunity. Clin. Exp. Immunol. 81, 334-338.

Tutschka, P. J., Beschorner, W. E., Allison, A. C., Burns, W. H., and Santos, G. W. (1979). Use of cyclosporin $\mathrm{A}$ in allogeneic bone marrow transplantation in the rat. Nature 280, 148-151.

Tutschka, P. J., and Santos, G. W. (1975). Bone marrow transplantation in the busulfan-treated rat. I. Effect of cyclophosphamide and rabbit antirat thymocyte serum as immunosuppression. Transplantation 20, 101-106.

Vaidya, S., Wang, C. C., Roorda, C., Billings, A., Rajaraman, S., and Fish, J. C. (1996). Prevention of graftversus-host disease by intrathymic injection of recipient-type splenocytes into donor. Transplantation 62 , 1366-1368.

van den Berg, T. K., Puklavec, M. J., Barclay, A. N., and Dijkstra, C. D. (2001). Monoclonal antibodies against rat leukocyte surface antigens. Immunol. Rev. 184, 109-116.
Vance, R. E., Kraft, J. R., Altman, J. D., Jensen, P. E., and Raulet, D. H. (1998). Mouse CD94/NKG2A is a natural killer cell receptor for the nonclassical major histocompatibility complex (MHC) class I molecule

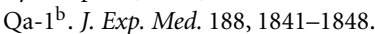

Velardi, A. (2012). Natural killer cell alloreactivity 10 years later. Curr. Opin. Hematol. 19, 421-426.

Vogelsang, G. B., Hess, A. D., Berkman, A. W., Tutschka, P. J., Farmer, E. R., Converse, P. J., et al. (1985). An in vitro predictive test for graft versus host disease in patients with genotypic HLA-identical bone marrow transplants. N. Engl. J. Med.313, 645-650.

Vogelsang, G. B., Hess, A. D., Gordon, G., and Santos, G. W. (1986). Treatment and prevention of acute graftversus-host disease with thalidomide in a rat model. Transplantation 41, 644-647.

Vogelsang, G. B., Hess, A. D., and Santos, G. W. (1988). Thalidomide for treatment of graft-versus-host disease. Bone Marrow Transplant. 3, 393-398.

Wang, X.-N., Collin, M., Sviland, L., Marshall, S., Jackson, G., Schulz, U., et al. (2006). Skin explant model of human graft-versus-host disease: prediction of clinical outcome and correlation with biological risk factors. Biol. Blood Marrow Transplant. 12, 152-159.

Wang, X.-N., Haniffa, M. A., Holtick, U., Collin, M. P., Jackson, G., Hilkens, C. M. U., et al. (2009). Regulatory $\mathrm{T}$-cell suppression of CD8 ${ }^{+}$T-cellmediated graft-versus-host reaction requires their presence during priming. Transplantation 88, 188-197.

Wang, X.-N., Lange, C., Schulz, U., Sviland, L., Eissner, G., Oliver, K. M., et al. (2002). Interleukin-10 modulation of alloreactivity and graftversus-host reactions. Transplantation 74, 772-778.

Welniak, L. A., Blazar, B. R., and Murphy, W. J. (2007). Immunobiology of allogeneic hematopoietic stem cell transplantation. Annu. Rev. Immunol. 25, 139-170.

Williams, A. F., Galfre, G., and Milstein, C. (1977). Analysis of cell surfaces by xenogeneic myelomahybrid antibodies: differentiation antigens of rat lymphocytes. Cell 12, 663-673.
Wilson, J., Cullup, H., Lourie, R., Sheng, Y., Palkova, A., Radford, K. J., et al. (2009). Antibody to the dendritic cell surface activation antigen CD83 prevents acute graftversus-host disease. J. Exp. Med. 206, 387-398.

Wolff, D., Frei, E., Hofmeister, N. Steiner, B., Kleine, H. D., Junghanss, C., et al. (2006). Methotrexatealbumin and aminopterin-albumin effectively prevent experimental acute graft-versus-host disease. Transplantation 82, 527-533.

Woollett, G. R., Barclay, A. N., Puklavec, M., and Williams, A. F. (1985). Molecular and antigenic heterogeneity of the rat leukocyte-common antigen from thymocytes and $\mathrm{T}$ and $\mathrm{B}$ lymphocytes. Eur. J. Immunol. 15, 168-173.

Xystrakis, E., Bernard, I., Dejean, A. S., Alsaati, T., Druet, P., and Saoudi, A. (2004a). Alloreactive CD4 T lymphocytes responsible for acute and chronic graft-versus-host disease are contained within the CD45RC high but not the CD45RC ${ }^{\text {low }}$ subset. Eur. J. Immunol. 34, 408-417.

Xystrakis, E., Dejean, A. S., Bernard, I., Druet, P., Liblau, R., GonzalezDunia, D., et al. (2004b). Identification of a novel natural regulatory CD8 T-cell subset and analysis of its mechanism of regulation. Blood 104, 3294-3301.

Zheng, H., Matte-Martone, C., Jain, D. McNiff, J., and Shlomchik, W. D. (2009). Central memory CD8 ${ }^{+} \mathrm{T}$ cells induce graft-versus-host disease and mediate graft-versus-leukemia. J. Immunol. 182, 5938-5948.

Zhou, S., Ueta, H., Xu, X. D., Shi, C., and Matsuno, K. (2008). Predominant donor $\mathrm{CD}_{103}{ }^{+} \mathrm{CD}^{+}{ }^{+} \mathrm{T}$ cell infiltration into the gut epithelium during acute GvHD: a role of gut lymph nodes. Int. Immunol. 20, 385-394.

Zhu, Z. X., Fan, L. Y., and Wang, Q. (2011). Simultaneous blockade of costimulatory signals CD28-CD80 and CD40-CD154 combined with monoclonal antibody against CD25 induced a stable chimerism and tolerance without graft-versus-host disease in rat. Eur. Surg. Res. 46, 109-117.

Zinöcker, S., Sviland, L., Dressel, R. and Rolstad, B. (2011a). Kinetics of lymphocyte reconstitution after allogeneic bone marrow transplantation: markers of graft-versus-host disease. J. Leukoc. Biol. 90, 177-187. doi:10.1189/jlb.0211067

Zinöcker, S., Wang, M.-Y., Gaustad, P., Kvalheim, G., Rolstad, B., and Vaage, J. T. (2011b). Mycoplasma contamination revisited: Mesenchymal stromal cells harboring Mycoplasma hyorhinis potently inhibit lymphocyte proliferation in vitro. PLoS ONE 6, e16005. doi:10.1371/journal.pone.0016005

Zinöcker, S., Wang, M.-Y., Rolstad, B., and Vaage, J. T. (2012). Mesenchymal stromal cells fail to alleviate experimental graft-versus-host disease in rats transplanted with major histocompatibility complex-mismatched bone marrow. Scand. J. Immunol. 76, 464-470. doi:10.1111/j.13653083.2012.02758.x

Zorn, E., Kim, H. T., Lee, S. J., Floyd, B. H., Litsa, D., Arumugarajah, S., et al. (2005). Reduced frequency of $\mathrm{FOXP}^{+}{ }^{+} \mathrm{CD} 4{ }^{+} \mathrm{CD} 25^{+}$regulatory $\mathrm{T}$ cells in patients with chronic graft-versus-host disease. Blood 106, 2903-2911.

Conflict of Interest Statement: The authors declare that the research was conducted in the absence of any commercial or financial relationships that could be construed as a potential conflict of interest.

Received: 04 September 2012; accepted: 08 November 2012; published online: 30 November 2012.

Citation: Zinöcker S, Dressel R, Wang $X-N$, Dickinson AM and Rolstad B (2012) Immune reconstitution and graftversus-host reactions in rat models of allogeneic hematopoietic cell transplantation. Front. Immun. 3:355. doi: 10.3389/fimmu.2012.00355

This article was submitted to Frontiers in Alloimmunity and Transplantation, a specialty of Frontiers in Immunology. Copyright (c) 2012 Zinöcker, Dressel, Wang, Dickinson and Rolstad. This is an open-access article distributed under the terms of the Creative Commons Attribution License, which permits use, distribution and reproduction in other forums, provided the original authors and source are credited and subject to any copyright notices concerning any third-party graphics etc. 